\title{
Ethnopharmacological survey of medicinal plants practiced by traditional healers and herbalists for treatment of some urological diseases in the West Bank/Palestine
}

Nidal Amin Jaradat ${ }^{1 *}$ (D, Abdel Naser Zaid ${ }^{1}$, Rowa Al-Ramahi ${ }^{1}$, Malik A. Alqub², Fatima Hussein ${ }^{1}, Z^{2}$ Zakaria Hamdan³, Mahmoud Mustafa ${ }^{4}$, Mohammad Qneibi ${ }^{2}$ and lyad $\mathrm{Ali}^{2}$

\begin{abstract}
Background: Throughout history, every civilization in the world used plants or their derivatives for treatment or prevention of diseases. In Palestine as in many other countries, herbal medicines are broadly used in the treatment of wide range of diseases including urological diseases. The main objective of this research is to study the use of herbal remedies by herbalists and traditional healers for treatment of various urological diseases in the West Bank regions of Palestine and to assess their efficacy and safety through the literature review of the most cited plants.

Method: The study included a survey part, plant identification and a review study. The first part was a crosssectional descriptive study. Face to face questionnaires were distributed to 150 traditional healers and herbalist in all regions of the West Bank of Palestine. The literature review part was to assess the most cited plants for their efficacy and toxicity.

Results: One hundred forty four herbalists and traditional healers accepted to participate in this study which was conducted between March and April, 2016. The results showed that 57 plant species belonging to 30 families were used by herbalists and traditional healers for treatment of various urinary tract diseases in Palestine. Of these, Apiaceae family was the most prevalent. Paronychia argentea, Plantago ovata, Punica granatum, Taraxacum syriacum, Morus alba and Foeniculum vulgare were the most commonly used plant species in the treatment of kidney stones, while Capsella bursa-pastoris, Ammi visnaga and Ammi majus were the most recommended species for treatment of urinary tract infections and Portulaca oleracea used for renal failure. In addition Curcuma longa and Crocus sativus were used for enuresis while Juglans regia, Quercus infectoria, Sambucus ebulus and Zea mays were used for treatment symptoms of benign prostate hyperplasia. Fruits were the most common parts used, and a decoction was the most commonly used method of preparation. Through literature review, it was found that Paronychia argentea has a low hemolytic effect and contains oxalic acid and nitrate. Therefore, it could be harmful to renal failure patients, also Juglans regia, Quercus infectoria and, Sambucus ebulus are harmful plants and cannot be used for treatment of any disease.
\end{abstract}

Conclusions: Our data provided that ethnopharmacological flora in the West Bank regions of Palestine can be quite wealthy and diverse in the treatments of urinary tract diseases. Clinical trials and pharmacological tests are required evaluate safety and efficacy of these herbal remedies.

Keywords: Ethnopharmacology, Urological diseases, Herbalists, Traditional healers, Palestine

\footnotetext{
* Correspondence: nidaljaradat@najah.edu

'Department of Pharmacy, Faculty of Medicine and Health Sciences,

An-Najah National University, Nablus P.O. Box 7, Palestine

Full list of author information is available at the end of the article
} 


\section{Background}

Traditional herbal medicine is an important part of all nations' history, therefore, an establishment of the original uses and local names of plants has significant potential societal benefits. Unfortunately, recently with the fast growth in the technical aspects of the world, loss of customs and various ethnic cultures, some of this information may disappear [1-3]. Since the beginning of history, human beings have used plants as medicine, and Ancient Arabic Medicine was influenced by medicinal practices in India, Persia, Mesopotamia, Spain, Rome and Greece [4].

Palestine had high ecosystem diversity due to its geographical location between Africa, Asia, and Europe and due to different climatic, zoogeographic, and phytogeographic zones, this creates great biological diversity $[5,6]$. In the West Bank regions of Palestine, traditional medicine is widely used especially in rural areas; this may be due to the political conflicts in this country and the cost of conventional drugs [7-9]. Hundreds of shrubs, trees, and herbal species used as antipyretics, analgesics, diuretics, laxatives, antimicrobial, antidiarrheal, emetics and cardio-tonics in the West Bank area of Palestine [10]. These plants are available and cheap because they grow wildly in nature or cultivated $[11,12]$.

The rich variety of approaches employed by herbalists and traditional healers to treat disorders and diseases of the urinary tract is indicative of the depth and breadth of indigenous medicine practiced among these traditional healers and herbalists in the twentieth century [12].

The Kidney is the organ that has numerous physiological functions. Its role is to maintain the homeostatic balance of body fluids and electrolytes. Kidneys are vital regulators of glucose metabolism, blood pressure, and erythropoiesis. Patients with kidney diseases have significant morbidity and mortality $[13,14]$.

There are many urologic diseases and disorders. According to the American Urological Association Foundation, the most commonly identified urological diseases include hyperplasia, benign prostate hyperplasia $(\mathrm{BPH})$, urinary tract infections, urethral and kidney stones, enuresis (urinary incontinence) and renal failure [15].

According to the Palestinian Central Bureau of Statistics and Ministry of Health annual report in 2014, the visits to the outpatient urological clinics of governmental hospitals in Palestine were 49,275 visits per year. Moreover, about $4 \%$ of death causes in Palestine were due to renal failure and other kidney diseases. In the USA, about 26 million American adults have kidney disease, and it is considered the 9th leading cause of death in the United States. Kidney diseases kill more people than breast or prostate cancer yearly [16-18].
For these reasons, this study aimed to collect data from herbalists and traditional healers about the folk herbal remedies, which have been utilized for treatment of urological diseases in the West Bank regions of Palestine and to verify their pharmacological and toxicological effects through literature review.

\section{Methods}

\section{Study areas}

West Bank is an important territory of Palestine. The climate in the West Bank is mostly Mediterranean, slightly colder in mountains and hills compared with the shorelines in the western lands. In the east, it includes the desert and the shoreline of the Dead Sea, both with dry and hot climate. The shores of the Dead Sea are about $430 \mathrm{~m}$ below sea level, and it is considered the Earth's lowest elevation on the land. Accordingly, all these factors explain the enormous diversity of the West Bank flora. This diversity is directly reflected in the distribution and diversification of agricultural patterns, from the rain-fed farming in the mountains (Jerusalem, Ramallah, Hebron, Nablus, Bethlehem, Salfeit) to an irrigated agriculture as in Jenin, Tobas, Toulkarem, Qalqilya and Jericho lands [19, 20].

\section{Selection of informants}

An ethnopharmacological survey (questionnaire-based cross-sectional descriptive study) was used. Areas visited included all regions of the West Bank/Palestine, including Nablus, Jenin, Tubas, Toulkarem, Salfeit, Qalqilya, Ramallah, Jericho, Jerusalem, Bethlehem and Hebron (Fig. 1) between March and April 2016. The Institutional Review Board (IRB) at An-Najah National University approved the study protocol and the informed consent forms (IRB number was 134/February/2016). The study was conducted in accordance with the requirements of the declarations of Helsinki (World Medical Association 2008), the current Good Clinical Practice (GCP) Guidelines (EME 1997) and the International Conference on Harmonization (ICH1996) Guidelines, and a written informed consent was obtained from the participants.

The objectives of the study were explained to the participants, they were not offered any incentives, and they were able to withdraw from this study at any time.

A total of 150 traditional healers and herbalists were interviewed in this study. 144 participants accepted to answer the questionnaire (102 males and 42 females), where 26 of them were from Hebron (16 males and 10 females), 18 from Jenin (12 males and 6 females), 17 from Jericho (14 males and 3 females), 16 Nablus and Qalqilya (12 males and 4 females from Nablus) (10 males and 6 females from Qalqilya), 14 from Toulkarem (12 males and 2 females), 11 from Ramallah (9 males and 2 females), 9 from Jerusalem (7 males and 2 


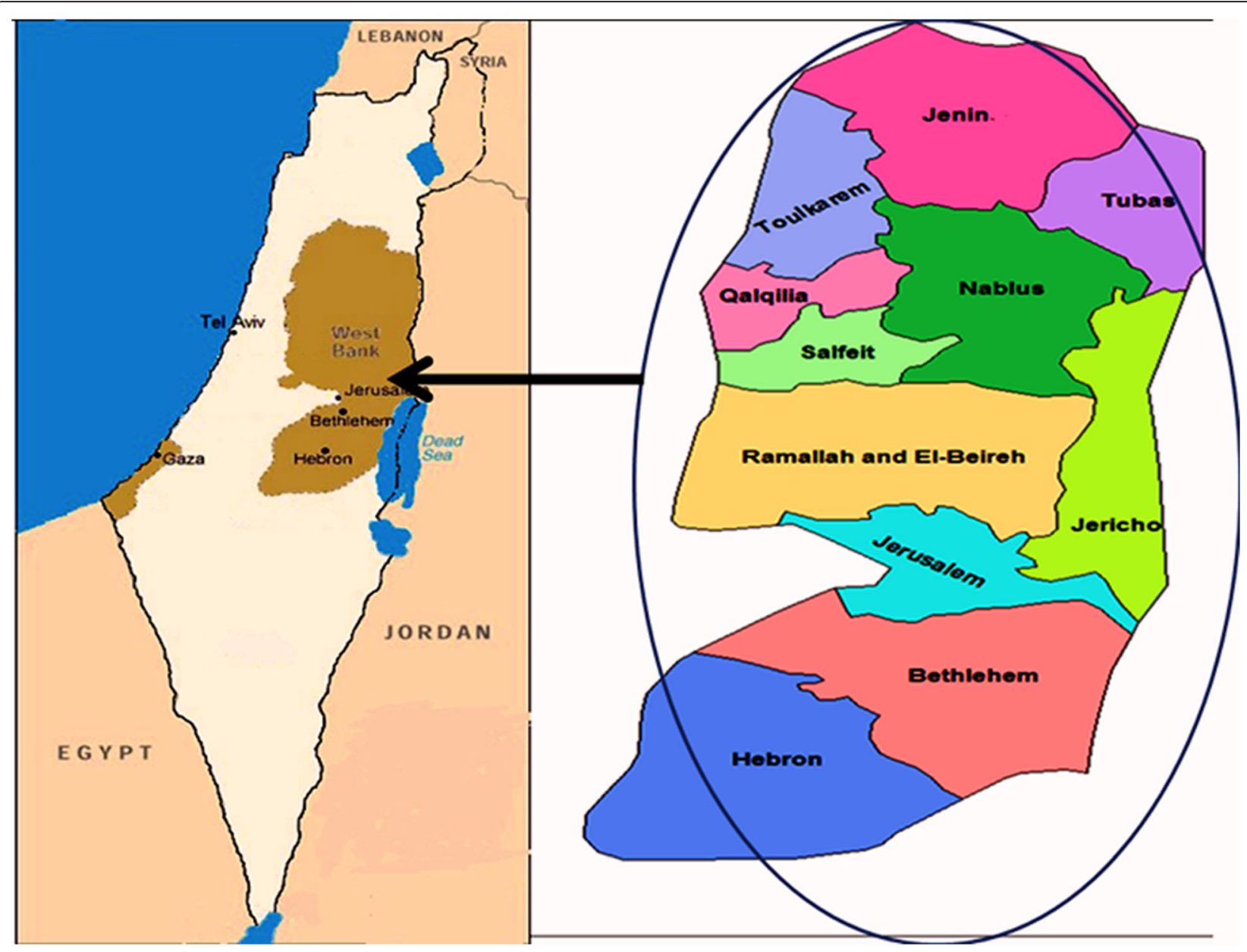

Fig. 1 The study area map showing all the surveyed regions in the West Bank/Palestine

females), 6 from Tubas and Jerusalem (4 males and 2 females from Tubas) and ( 3 males and 3 females from Jerusalem), and 5 from Salfeit (3 males and 2 females), from 11 regions of the West Bank Area of Palestine. They were from different ages (22-91 years) and were selected with the help of local people. The selected healers were well known in the community due to their long practice of providing services related to traditional health care. All the participants (i.e., 144) were asked to provide information on the plant(s) that they use for treating the urinary tract diseases, parts of the plants used such as leaves, roots, flowers, stems and seeds, methods of preparation (e.g decoction, juice, infusion, powder), and methods of administration (either orally or topically). In addition to their opinion about the advantages of herbal remedies.

The study was a face to face questionnaire. This method has proven to be a very practical and useful option of data collection. The survey was anonymous, pretested by a pilot study for reliability, validity and clarity of the questionnaire. Meanwhile, the duration of the interviews ranged from 20 to $60 \mathrm{~min}$, with one visit per interviewee in each case. Interviews were conducted in Arabic, the local language of the informants and the plant names were given in Arabic and later translated into English and Latin using reference books as well as about $50 \%$ of these Arabic names were linked to an actual right scientific name [21-23].

\section{Plant identification}

The collected plant samples from these informants were stored in the pharmacognosy laboratory at the Pharmacy Department, An-Najah National University in appropriate glassware and individual herbarium wooden frames. They were identified later by a team of teaching assistants and technicians under the supervision of the pharmacognosist (Dr. Nidal Jaradat), all fifty-seven plants' species that were mentioned by informants, were identified by using photographs from reference books and dried herbarium specimens $[24,25]$. 


\section{Data analysis}

The frequency of citation (FC) for all plants species in this study were calculated by using the following formula:

$\mathrm{FC}=$ (Number of times a particular species was mentioned by herbalists and traditional healers/a total number of occasions that all species were mentioned) $\times 100$ [24].

To evaluate the relative importance of plants in indigenous healthcare systems, the use value (UV) is used as a micro-statistical tool, which reflects people interaction with specific plants as the best treatments for urinary tract diseases. It is a quantitative method that can be used to prove the relative importance of species known locally. It can be calculated according to the following equation:

$$
\mathrm{UV}=\frac{\sum U}{n}
$$

Where UV is the use value of a species; $U$ is the number of citations per species; $n$ is the number of informants [25].

Factor of informant's consensus $\left(F_{i c}\right)$ was calculated according to the following equation:

$$
F_{i c}=\frac{N u r-N t}{N u r-1}
$$

Where Nur is the number of use citations in urinary tract disease category, and $\mathrm{Nt}$ is the number of taxa used for the treatment of these diseases.

This factor is employed to indicate how homogenous the information is. $F_{i c}$ value is close to 0 if plants are chosen randomly, or if informants do not exchange information about their use. High values of Fic (close to 1) occur when there is a clear selection criterion in the community and if information is frequently exchanged between informants [26].

The Choice Value (CV) method is a valuable assessment tool to measure related plant species for treatment of urinary tract diseases [27].

The $\mathrm{CV}$ is calculated as in the following equation:

$$
C V \text { species }=\frac{P c s}{S c} \times 100
$$

Pcs: percent of informants that cited certain plant species for the treatment of urinary tract disease.

Sc: is the total number of species mentioned for treatment of disease by all informants. Choice values are ranked from 0 to 100 with 100 indicating complete preference and fewer alternatives.

The significance of medicinal plant families was assessed using the Family Use Values (FUV), which was calculated according to the following equation:

$$
F U V=\frac{U V s}{(n s)}
$$

where, $U V s=$ use values of the taxa, and $n s=$ total number of species within each family which were used for the treatment of urological diseases in the West Bank area of Palestine [28].

\section{Review study}

A literature review was conducted by a systematic search of the scientific literature, which was published before January 2017, by using Medline, Pubmed, Scopus and Google Scholar electronic searching machines. It cited most of the plants which had FC higher than 50\% and their applications in the treatment of urological disease. The investigators practiced the following Keywords: folk uses for urinary tract, ethnopharmacological uses urinary tract, traditional methods of urinary tract, evidence-

\begin{tabular}{|c|c|}
\hline Variable & $\begin{array}{l}\text { Number of herbalists and } \\
\text { traditional healers }(N=144)\end{array}$ \\
\hline \multicolumn{2}{|l|}{ Gender } \\
\hline Male & 102 \\
\hline Female & 42 \\
\hline \multicolumn{2}{|l|}{ Education level } \\
\hline No formal education & 32 \\
\hline Elementary & 14 \\
\hline Secondary school & 28 \\
\hline High secondary school & 44 \\
\hline Undergraduate & 22 \\
\hline Graduate (higher education) & 4 \\
\hline \multicolumn{2}{|l|}{ Residency } \\
\hline Bethlehem & 6 \\
\hline Hebron & 26 \\
\hline Jenin & 18 \\
\hline Jericho & 17 \\
\hline Jerusalem & 9 \\
\hline Nablus & 16 \\
\hline Qalqilya & 16 \\
\hline Ramallah & 11 \\
\hline Salfeit & 5 \\
\hline Tubas & 6 \\
\hline Toulkarem & 14 \\
\hline Age (mean $\pm S D$ ) years & $54.8 \pm 17.9$ \\
\hline Experience (mean $\pm \mathrm{SD}$ ) years & $29.1 \pm 10.9$ \\
\hline
\end{tabular}
based uses, toxicities and side effects for individual plant names.

Table 1 Sociodemographic factors related to the respondents 


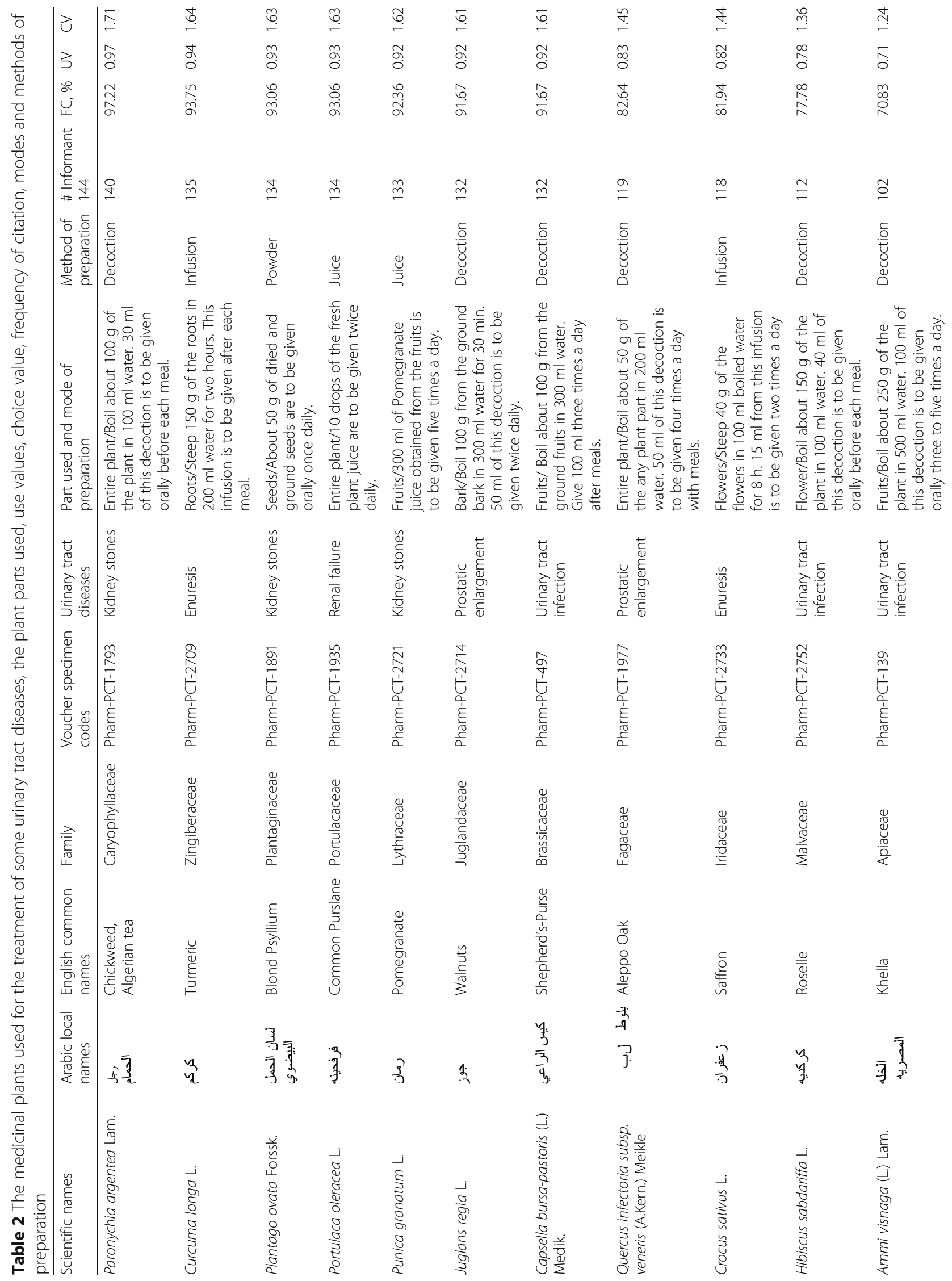




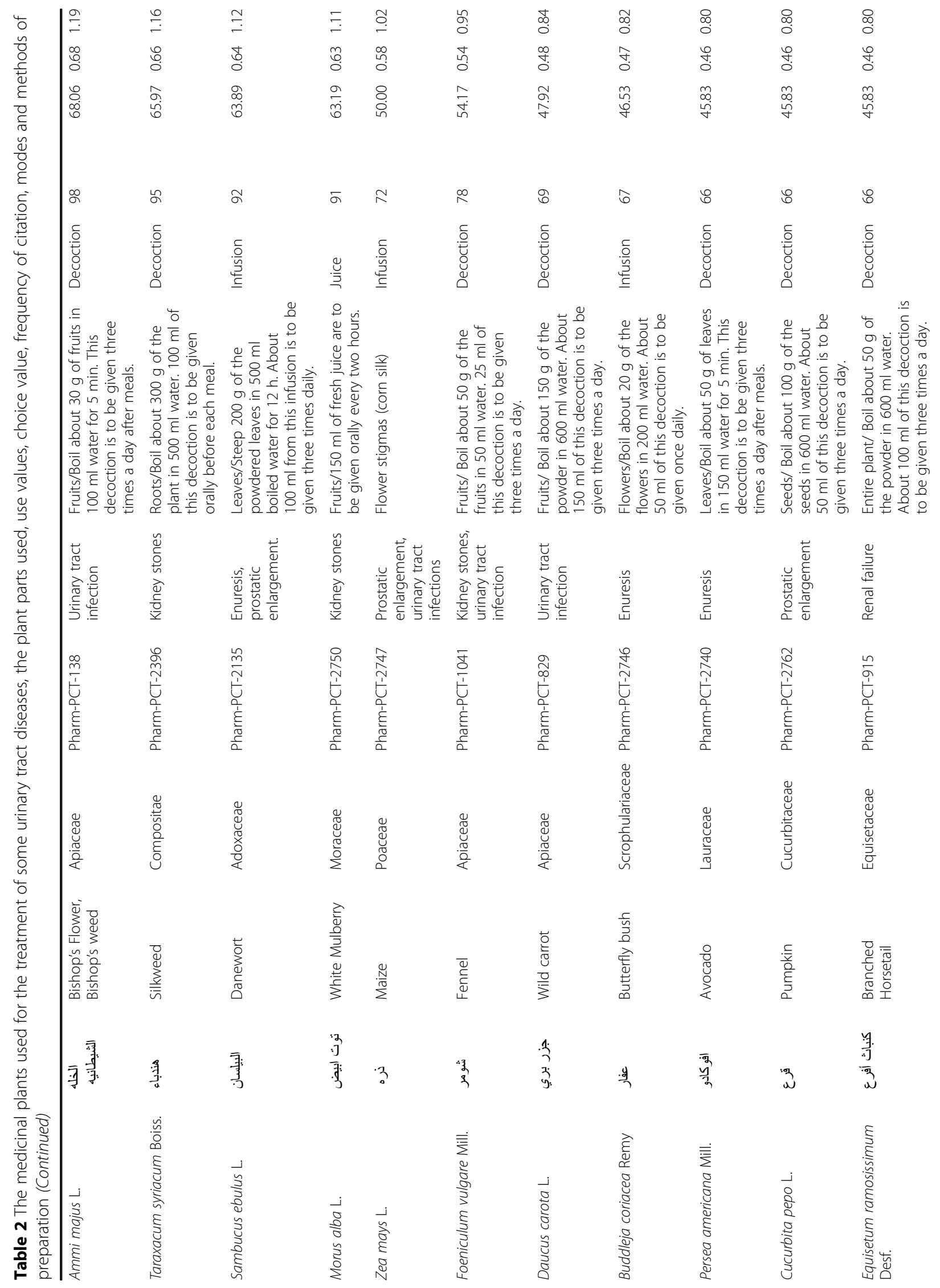




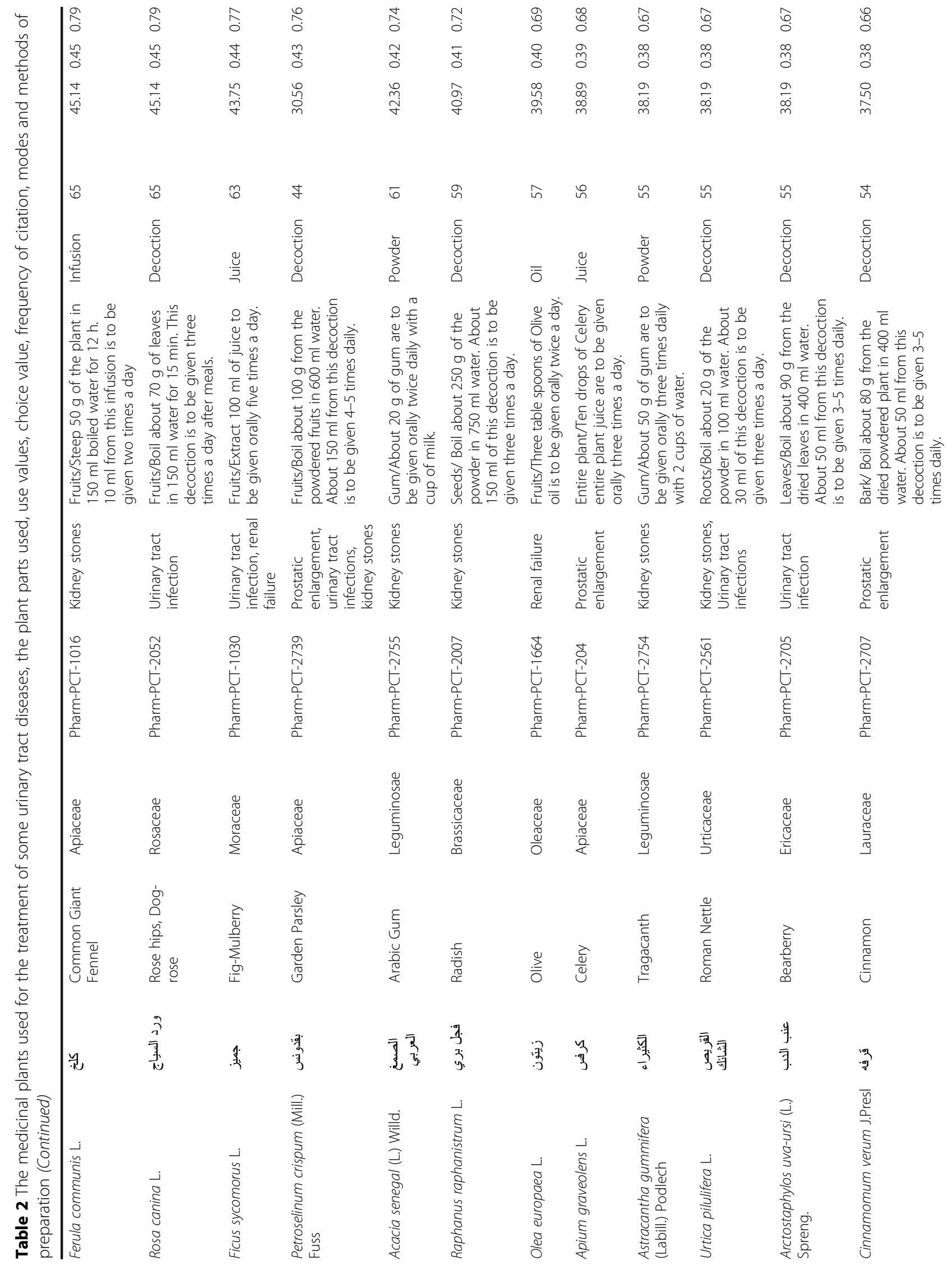




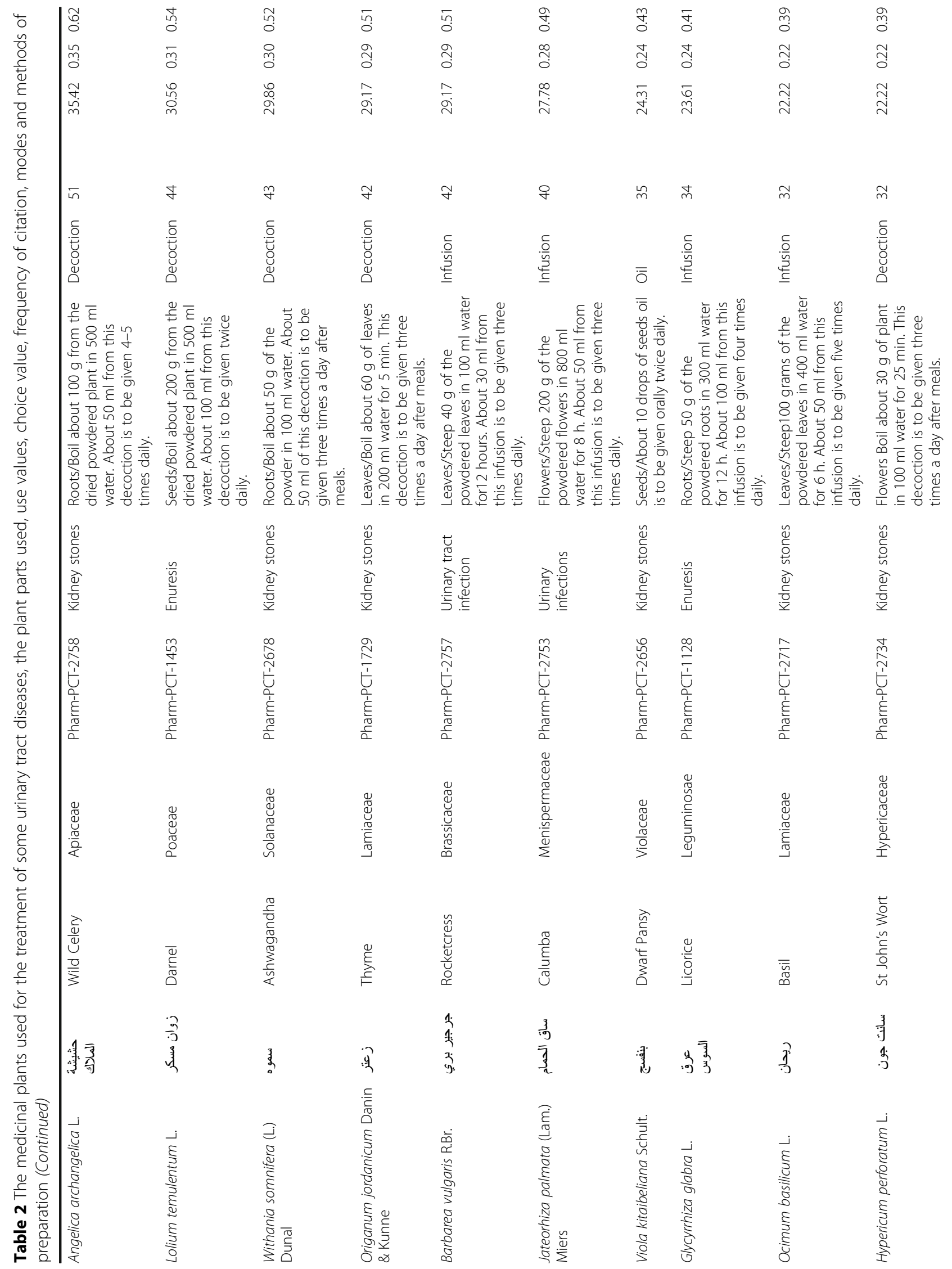




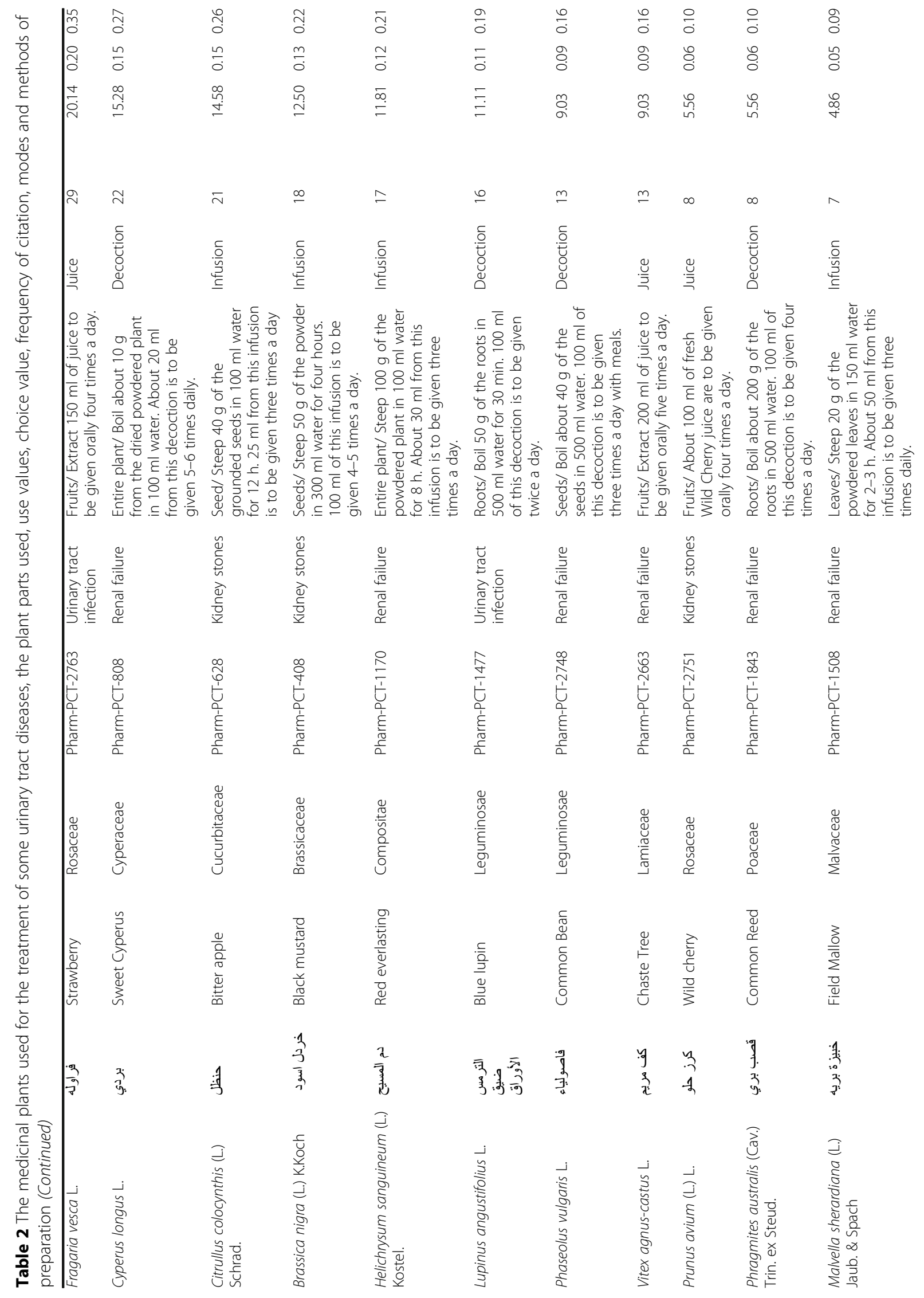




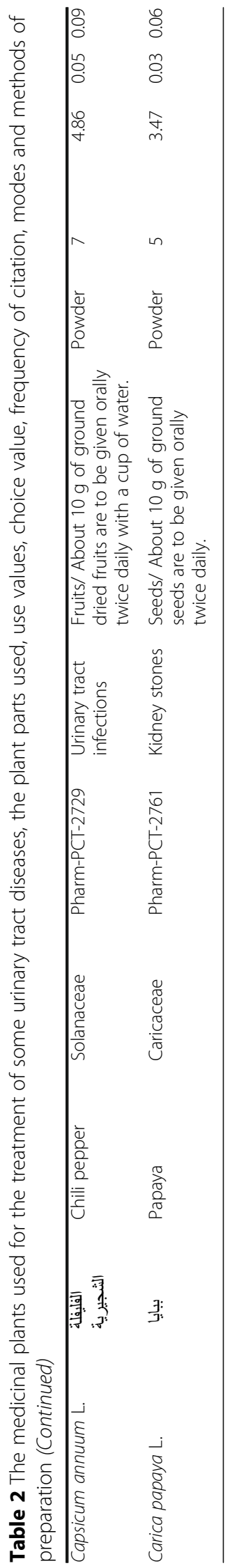


Table 3 Factor of informant's consensus $\left(F_{i c}\right)$ for the studied urinary tract diseases

\begin{tabular}{llll}
\hline Urinary tract disease categories & $\mathrm{Nt}$ & Nur & $\mathrm{F}_{\mathrm{ic}}$ \\
\hline Kidney stones & 22 & 1202 & 0.98 \\
Urinary infection & 17 & 912 & 0.98 \\
Prostatic enlargement & 8 & 544 & 0.99 \\
Enuresis & 7 & 496 & 0.99 \\
Renal failure & 10 & 370 & 0.98 \\
\hline
\end{tabular}

Where; Nur is the number of use citations in urinary tract disease category, $\mathrm{Nt}$ is the number of taxa used for treatment of these diseases.

\section{Results}

\section{Socio-demographic factors}

As shown in Table 1, most of the respondents who worked in this field were males. Most of them had high educational levels. In fact, $30.56 \%$ of the interviewed were secondary school graduates. The majority of respondents were from areas of the West Bank that mostly depended on agriculture or grazing as a mean of income (Hebron, Jenin, and Jericho).

Regarding training and knowledge acquisition; (i) 77\% of the respondents acquired their skills through observing their family members, (ii) $21 \%$ gained their skills through coursework and apprenticeship, (iii) and about $2 \%$ claimed they had a divine gift for the healing of certain diseases, which means that most of them had this knowledge through their families' historical healing knowledge skill.

Data collection of ethnopharmacological plants.

The fruits were the most commonly used parts of plants for the treatment of urinary tract diseases followed by seeds and roots. The modes and methods of

Table 4 Medicinal plant families used for treatment of urinary tract diseases and the family use value (30 families)

\begin{tabular}{llll}
\hline Number & Families & $\begin{array}{l}\text { Number } \\
\text { of taxa }\end{array}$ & $\begin{array}{l}\text { Family } \\
\text { use value }\end{array}$ \\
\hline 1. & Apiaceae & 8 & 26.67 \\
2. & Lamiaceae & 5 & 16.67 \\
3. & Leguminosae & 5 & 16.67 \\
4. & Brassicaceae & 4 & 13.33 \\
5. & Poaceae & 3 & 10.00 \\
6. & Rosaceae & 3 & 10.00 \\
7. & Compositae & 2 & 6.67 \\
8. & Cucurbitaceae & 2 & 6.67 \\
9. & Malvaceae & 2 & 6.67 \\
10. & Moraceae & 2 & 6.67 \\
11. & Solanaceae & 2 & 6.67 \\
12. & Other families with one citation & 19 & 63.33 \\
\hline
\end{tabular}

preparation varied considerably from one healer to another; however, all of these methods were administered orally as described by the interviewees and shown in Table 2.

In the case of kidney stones, the highest use values were for Paronychia Argentina, Plantago ovata, Punica granatum, Taraxacum syriacum, Morus alba and Foeniculum vulgare, respectively. In the case of urinary tract infections, the highest use values were for Capsella bursa-pastoris, Ammi visnaga, and Ammi majus, respectively. Besides, the maximum use value in case of renal failure was for Portulaca oleracea while the highest use values in the case of enuresis were for Curcuma longa and Crocus sativus, respectively. In the case of prostatic enlargement, the highest use values were for Juglans regia, Quercus infectoria, Sambucus ebulus and Zea mays, respectively. Furthermore, the frequencies of citation for these plants species were more than $50 \%$.

The factor of informant's consensus $\left(\mathrm{F}_{\mathrm{ic}}\right)$ was calculated for medicinal plants used for the treatment of various urinary tract diseases (i.e., 0.99 for Benign Prostate Hyperplasia (BPH) and enuresis and 0.98 in a case of kidney stones disease, urinary tract infection and renal failure). The calculated $F_{i c}$ value obtained for the reported diseases indicated the degree of shared knowledge among informants for the treatment of these urinary tract diseases by certain medicinal plants as shown in Table 3.

Ethnopharmacological information obtained from the study area on medicinal plants used in the treatment of various urinary tract diseases revealed that 57 plant species belonging to 30 families. All of the Latin scientific names have been checked with www.theplantlist.org on March 10, 2016.

As presented in Table 4, the family use value was the highest for Apiaceae family, which was 26.67, where the most common plant parts used were fruits, seeds, and roots, respectively as shown in Fig. 2.

\section{Pharmaceutical preparations}

The methods of preparation were decoctions, infusions, juice, oil, and powder. Decoctions and infusions were the most frequently used methods of preparation as presented in Fig. 3.

The most common urinary tract disease treated with herbal remedies was kidney stones followed by urinary tract infections, renal failure, Benign Prostate Hyperplasia $(\mathrm{BPH})$ and enuresis as reported in Fig. 4.

\section{Literature review}

For all the listed above plants, a literature review was investigated, where it represented their ethnopharmacological use against urinary tract diseases regionally, internationally and globally. Also, in-vitro as well as in-vivo 


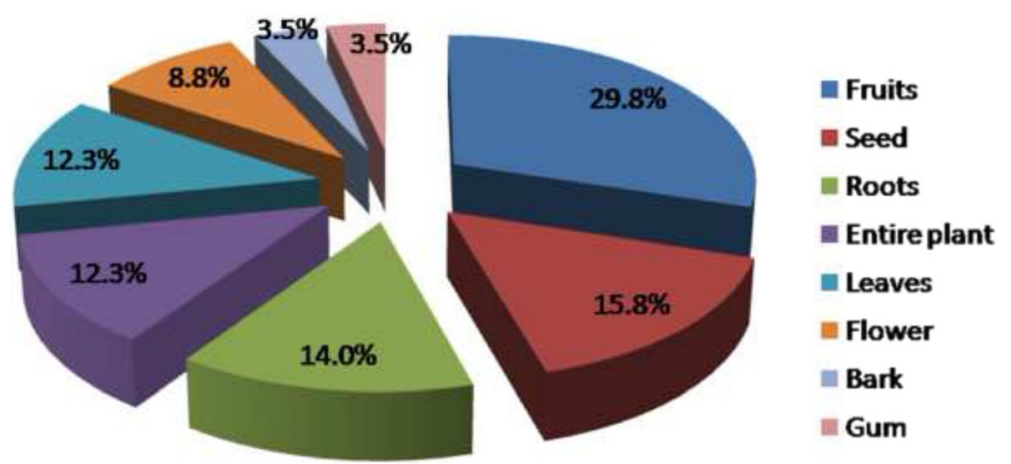

Fig. 2 The frequency of the used parts of medicinal plants in the treatment of some urinary tract diseases

studies and their toxic or adverse reactions were reviewed for plants which had FC value more than 50\%, using electronic databases and the results were summarized in Table 5.

\section{Discussion}

In the West Bank area of Palestine, the folk medicine has been trusted and highly appreciated, and many patients go to herbalists or traditional herbal healers to get benefit from this field. In fact, herbal medicine is considered the most used complementary and alternative medicine and this part of complementary and alternative medicines are widely used among patients suffering from urinary tract diseases throughout the world. Most practitioners are males, and this was confirmed in this study; some of them have university degrees.

All over the world, the prevalence of kidney diseases varies significantly from country to country. Epidemiological data on the occurrence of kidney stone was about $12 \%$ of global population with a recurrence rate of $70-80 \%$ in males and $47-60 \%$ in females [29].

According to the use value results, the highest use values for medicinal plants, which were utilized for the treatment of kidney stones, were for Paronychia argentea, Plantago ovata, Punica granatum, Taraxacum syriacum, Morus alba, and Foeniculum vulgare. The highest use values for medicinal plants used for treatment of urinary tract infections were for Capsella bursa-pastoris, Ammi visnaga, and Ammi majus, while the highest use value for plants used for treatment of renal failure was for Portulaca oleracea as well as the highest use values for medicinal plants used for treatment of enuresis were for Curcuma longa and Crocus sativus. Furthermore the maximum use values for plants used for treatment of benign prostate hyperplasia were for Juglans regia, Quercus infectoria, Sambucus ebulus and Zea mays.

Table 5 showed that Paronychia argentea, Punica granatum, Morus alba, and Foeniculum vulgare were used in the folk medicine in many countries for the treatment of kidney stones. The evidence-based effects for this disease were documented for Paronychia argentea, Plantago ovata, Punica granatum, Morus alba, and Foeniculum vulgare, whereas Taraxacum syriacum lacked any evidence-based use for treatment of kidney stone. Moreover, specific attention must be considered during consumption of Paronychia argentea extract, which has a low hemolytic effect.
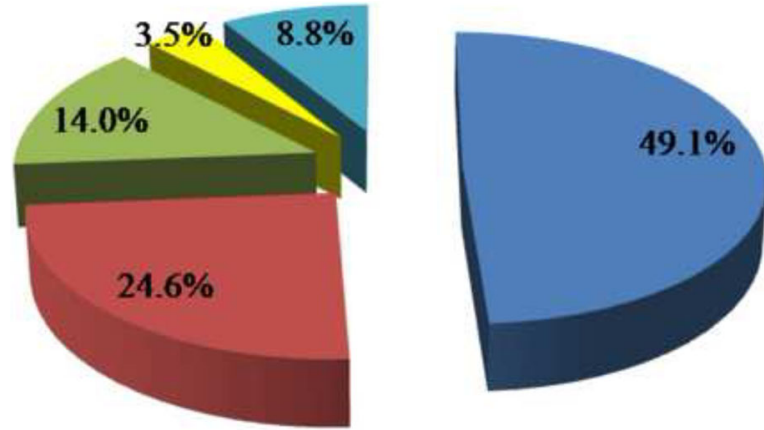

- Decoction
- Infusion
= Juice
Oil
= Powder

Fig. 3 The frequency of preparation methods of medicinal plants for treatment of some urinary tract diseases 


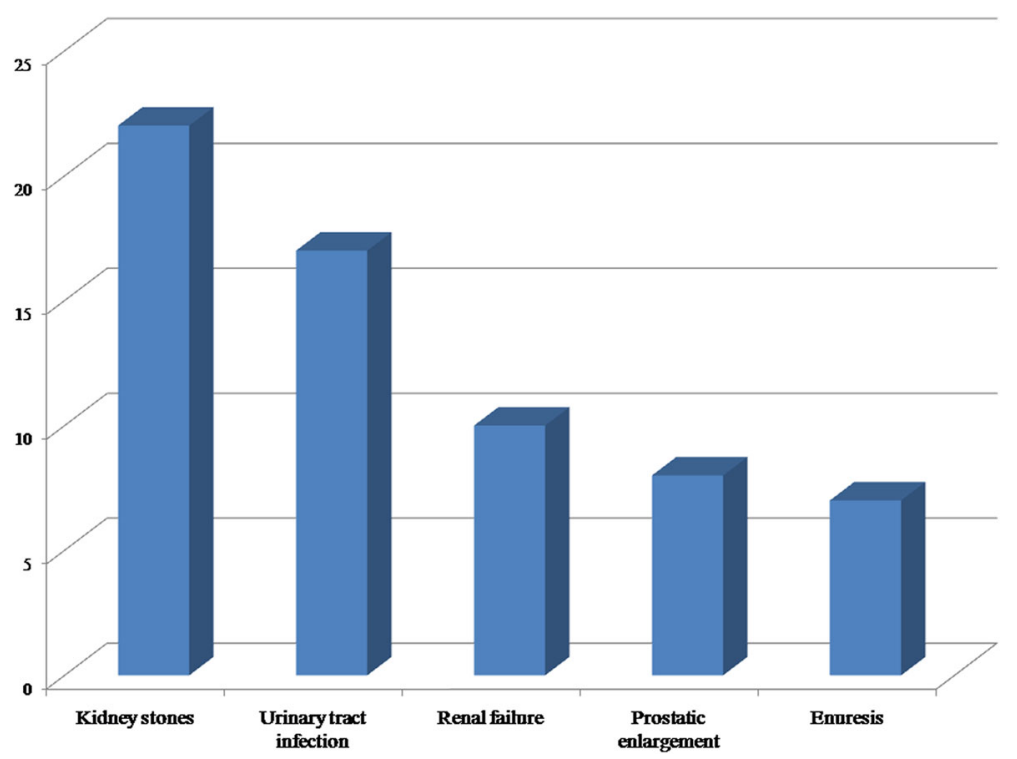

Fig. 4 The frequency of urinary tract diseases mentioned by herbalists and traditional healers in the West Bank area of Palestine

Regarding the most cited plants which were used for the treatment of urinary tract infections, all of them applied in the folk medicine in many countries and their antibacterial effect approved scientifically, but all of them may have harmful effects due to their adverse reactions and toxicological effect. Mean while the most cited plant for treatment of renal failure was Portulaca oleracea which is used in India and Sri Lanka for the treatment of this disease also, but unfortunately, this plant contains oxalic acid and nitrate. Therefore, high consumption of this plant is harmful to patients suffering from renal failure. Moreover, the most cited plants for treatment of enuresis were Curcuma longa and Crocus sativus which was not mentioned before in any folk or evidence-based medicines for the treatment of this disease and their toxicological effects were not reported.

The most cited plants which were used for the treatment of benign prostate hyperplasia (prostatic enlargement) were; Juglans regia, Sambucus ebulus and Zea mays. These plants had evidence-based studies to be useful for the treatment of this disease, but it is important to keep in mind that Juglans regia, Quercus infectoria and, Sambucus ebulus are harmful as mentioned in the literature review and cannot be used for treatment of any disease.

Over all, there are quite a few phytopharmaceuticals which can be used effectively for the treatment of the urinary tract diseases in the pharmaceutical markets. For that further phytochemical and pharmacological screenings is required to investigate new drugs from the mentioned plants in this study, especially those which have high use values and can be used safely.

\section{Conclusion}

The traditional herbal medicine has gradually become more popular, and the need for promoting awareness is perceived. This study showed that traditional herbal medicine is playing a significant role for treatment of urological diseases in the West Bank of Palestine. Based on that, all the plants in this study with high use value should have further phytochemical and pharmacological screenings to test for safety and efficacy. Despite the fact that many of the herbals are currently used by local and international herbalists and traditional healers, serious attention must be given toward many of these products, since they have serious adverse effects and toxicities. Curcuma longa and Crocus sativus were the most cited plants for treatment of enuresis. These plants could be of interest for additional research since they have not been mentioned before in any folk or evidence-based medicines for the treatment of this disease and their toxicological effects were not reported. Also, it is important to keep in mind that Juglans regia, Quercus infectoria and, Sambucus ebulus are harmful and cannot be used for the treatment of any disease.

\section{Abbreviations}

BPH: Benign Prostate Hyperplasia; CV: Choice Value; FC: frequency of citation: $\mathrm{F}_{\mathrm{ic}}$ : Factor of Informant's Consensus; IRB: Institutional Review Board; ns: Total Number of Species; Nt: Number of Taxa; Nur: is the number of use; UV: Use Value; UVs: Use Values of the Species 


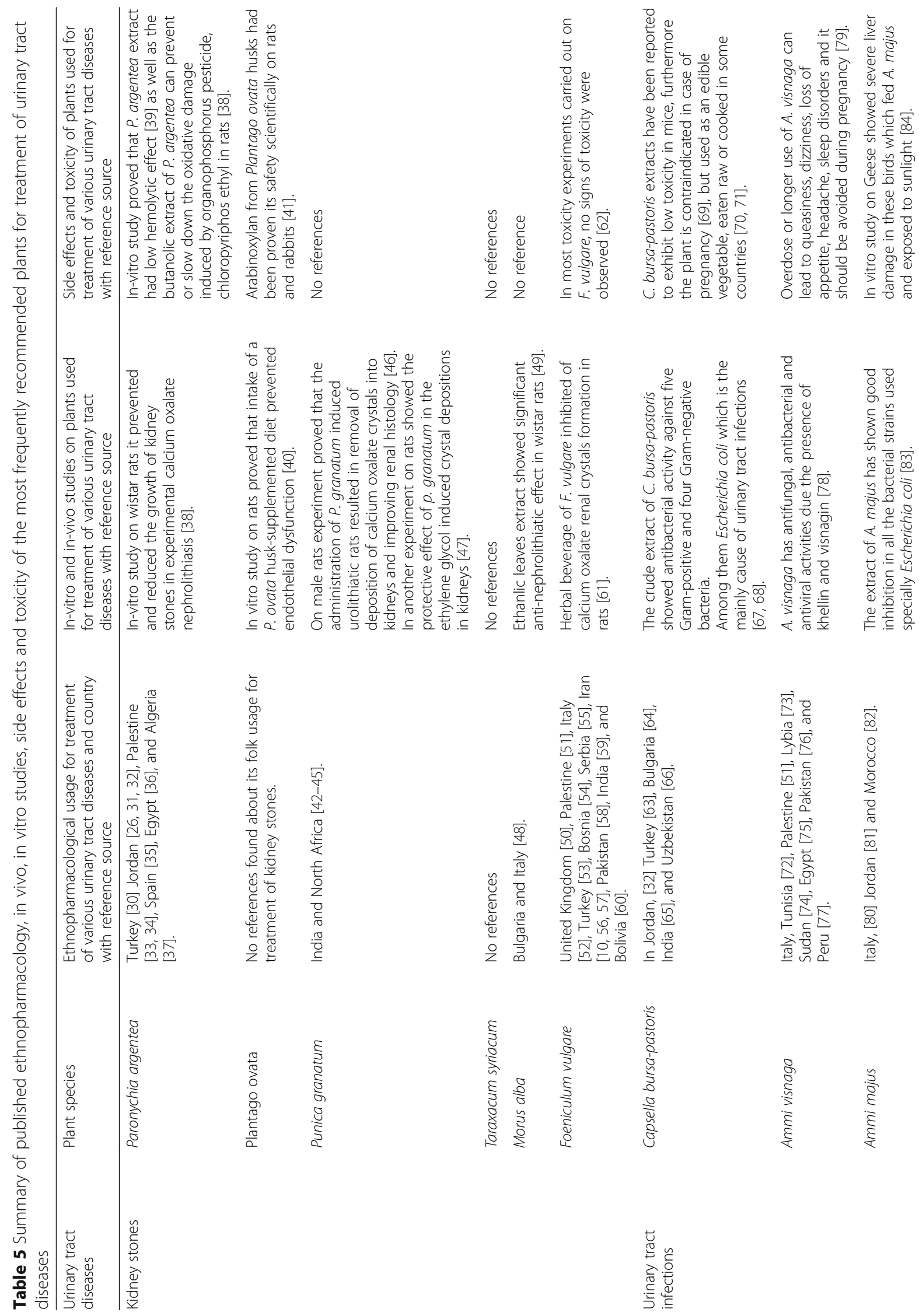




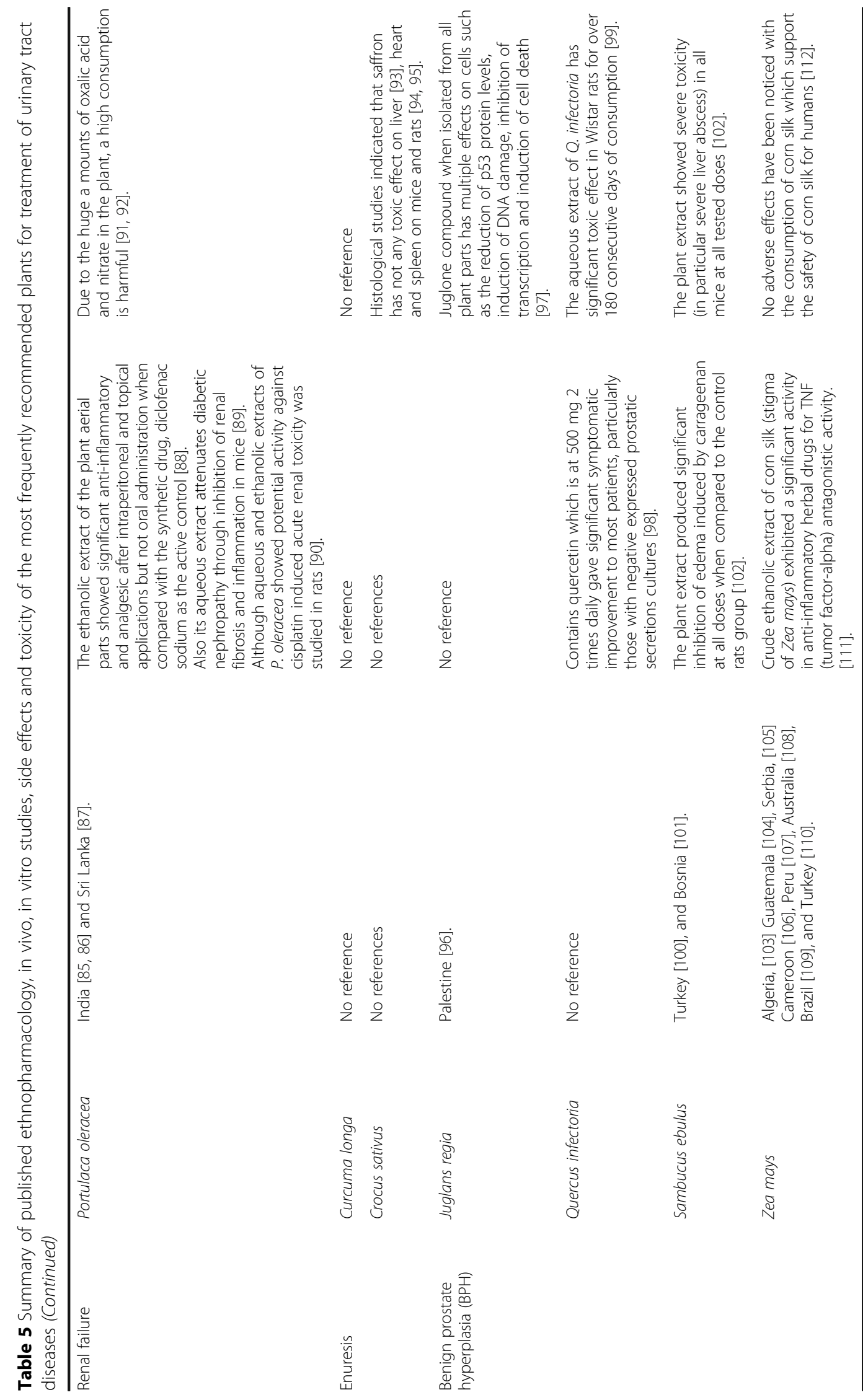




\section{Acknowledgements}

We would like to thank all the herbalists and herbal practitioner healers in the West Bank/ Palestine and all participants in the study.

\section{Authors' contributions}

NJ conceived and designed the study, analyzed the data obtained. This paper was drafted by ANZ, RAI-R, MAA, FH, ZH, MM, MQ and IA. All authors read and approved the final manuscript.

\section{Funding}

None.

\section{Availability of data and materials}

Data are all contained within the article.

\section{Competing interests}

The authors declare that they have no financial and/or non-financial competing interests.

\section{Consent for publication}

All authors gave their consent for the publication of the manuscript for Nidal Jaradat to be the corresponding author.

\section{Ethics approval and consent to participate}

The study aims, protocols and the informed consent forms were approved by the Institutional Review Board (IRB) at An-Najah National University (IRB archived number 134/February/2016). All participants agreed to their involvement in our study in our manuscript.

\section{Publisher's Note}

Springer Nature remains neutral with regard to jurisdictional claims in published maps and institutional affiliations.

\section{Author details}

${ }^{1}$ Department of Pharmacy, Faculty of Medicine and Health Sciences, An-Najah National University, Nablus P.O. Box 7, Palestine. ${ }^{2}$ Department of Biomedical Sciences, Faculty of Medicine and Health Sciences, An-Najah National University, Nablus P.O. Box 7, Palestine. ${ }^{3}$ Nephrology Unit, Internal Medicine Department, An-Najah National University Hospital, Nablus, Palestine. ${ }^{4}$ Department of Urology, Faculty of Medicine and Health Sciences, An-Najah University Hospital, An-Najah National University, Nablus P.O. Box 7, Palestine.

Received: 15 December 2016 Accepted: 26 April 2017

Published online: 08 May 2017

\section{References}

1. Muthu C, Ayyanar M, Raja N, Ignacimuthu S: Medicinal plants used by traditional healers in Kancheepuram District of Tamil Nadu, India J Ethnobiol Ethnomed 2006, 2(1):1

2. Bağcı Y. Ethnobotanical features of Aladağlar (Yahyalı, Kayseri) and its vicinity. Herb J Systc Bot. 2000;7:89-94.

3. Fabricant DS, Farnsworth NR. The value of plants used in traditional medicine for drug discovery. Electron J Environ Agric Food Chem. 2001;109:69-75

4. Petri RP Jr, Delgado RE, McConnell K. Historical and cultural perspectives on integrative medicine. Med Acupunct. 2015;27(5):309-17.

5. Saad B: Integrating traditional Greco-Arab and Islamic diet and herbal medicines in research and clinical practice. In: Phytotherapies: Efficacy, Safety, and Regulation. edn. United States: John Wiley \& Sons, Inc: 2015: 142-182.

6. Ali-Shtayeh MS, Jamous RM, Al-Shafie JH, Elgharabah WA, Kherfan FA. Traditional knowledge of wild edible plants used in Palestine (Northern West Bank): a comparative study. J Ethnobiol Ethnomed. 2008;4(1):13-9.

7. Jaradat NA, Shawahna R, Eid AM, Al-Ramahi R, Asma MK, Zaid AN. Herbal remedies use by breast cancer patients in the West Bank of Palestine. J Ethnopharmacol. 2016;178:1-8.

8. Jaradat NA, Ayesh OI, Anderson C. Ethnopharmacological survey about medicinal plants utilized by herbalists and traditional practitioner healers for treatments of diarrhea in the West Bank/Palestine. J Ethnopharmacol. 2016;182:57-66
9. Ali-Shtayeh MS, Jamous RM, Jamous RM. Traditional Arabic Palestinian ethnoveterinary practices in animal health care: a field survey in the West Bank (Palestine). J Ethnopharmacol. 2016;182:35-49.

10. Jaradat N. Ethnopharmacological survey of natural products in palestine. An-Najah Univ J Res (N Sc). 2005;19:14-67.

11. Alkowni R, Sawalha K. Biotechnology for conservation of palestinian medicinal plants. J Agr Sci Tech. 2012;8(4):1285-99.

12. Abu-Rabia A. Urinary diseases and ethnobotany among pastoral nomads in the Middle East. J Ethnobiol Ethnomed. 2005;1(1):1.

13. Hall JE. Guyton and hall textbook of medical physiology. UK: Elsevier Health Sciences; 2015.

14. Satlin LM, Bockenhauer D. Physiology of the developing kidney: potassium homeostasis and its disorder. Pediatr Nephrol. 2016;17:219-46.

15. Abrams P, Chapple C, Khoury S, Roehrborn C, De la Rosette J. Evaluation and treatment of lower urinary tract symptoms in older men. J Urol. 2013;189(1):S93-S101.

16. Bitar J. Health annual report Palestine 2014. Palestinian Health Information Center: State of Palestine; 2015.

17. Murphy S, Xu J, Kochanek K, Bastian B. Deaths: final data for. National vital statistics reports: from the Centers for Disease Control and Prevention, National Center for Health Statistics, National Vital Statistics System 2016. 2013;64(2):1-119.

18. Siegel R, Naishadham D, Jemal A. Cancer statistics, 2013. CA Cancer J Clin. 2013;63(1):11-30.

19. Ali-Shtayeh M, Jamous RM. Red list of threatened plants of the West Bank and Gaza strip and the role of botanic gardens in their conservation. Biodivers Environ Sci. 2002;2:1-46.

20. Ali-Shtayeh MS, Jamous RM, Al-Shafie JH, Elgharabah WA, Kherfan FA, Qarariah KH, Isra'S K, Soos IM, Musleh AA, Isa BA. Traditional knowledge of wild edible plants used in Palestine (Northern West Bank): a comparative study. J Ethnobiol Ethnomed. 2008;4(1):1-9.

21. Evans WC. Trease and Evans' pharmacognosy. UK: Elsevier Health Sciences; 2009

22. Iwu MM. Handbook of African medicinal plants. United States: CRC press; 2014

23. Ghazanfar SA. Handbook of Arabian medicinal plants: United States: CRC Press; 1994.

24. Dey AK, Rashid MMO, Millat MS, Rashid MM. Ethnobotanical survey of medicinal plants used by traditional health practitioners and indigenous people in different districts of Chittagong division, Bangladesh. Int J Pharm Sci. 2014;3:01-7.

25. Hoffman B, Gallaher T. Importance indices in ethnobotany. Ethnob Res Appl. 2007:5:201-18.

26. Alzweiri M, Al Sarhan A, Mansi K, Hudaib M, Aburjai T. Ethnopharmacological survey of medicinal herbs in Jordan, the Northern Badia region. J Ethnopharmacol. 2011;137(1):27-35.

27. Bolson M, Hefler SR, Dall El, Chaves O, Junior AG, Junior ELC. Ethnomedicinal study of plants used for treatment of human ailments, with residents of the surrounding region of forest fragments of Paraná, Brazil. J Ethnopharmacol. 2015;161:1-10.

28. Upadhya V, Hegde HV, Bhat S, Hurkadale PJ, Kholkute S, Hegde G. Ethnomedicinal plants used to treat bone fracture from north-Central western Ghats of India. J Ethnopharmacol. 2012;142(2):557-62.

29. Tiwari A, Soni V, Londhe V, Bhandarkar A, Bandawane D, Nipate S. An overview on potent indigenous herbs for urinary tract infirmity: urolithiasis. Asian J Pharm Clin Res. 2012;5(1):7-12.

30. Yeşilada E, Honda G, Sezik E, Tabata M, Goto K, Ikeshiro Y. Traditional medicine in Turkey IV. Folk medicine in the Mediterranean subdivision. J Ethnopharmacol. 1993;39(1):31-8.

31. Braca A, Bader A, Siciliano T, De Tommasi N. Secondary metabolites from Paronychia Argentea. Magn Reson Chem. 2008;46(1):88-93.

32. Aburjai T, Hudaib M, Tayyem R, Yousef M, Qishawi M. Ethnopharmacological survey of medicinal herbs in Jordan, the Ajloun Heights region. J Ethnopharmacol. 2007;110(2):294-304.

33. Said O, Khalil K, Fulder S, Azaizeh H. Ethnopharmacological survey of medicinal herbs in Israel, the Golan Heights and the West Bank region. J Ethnopharmacol. 2002;83(3):251-65.

34. Ali-Shtayeh MS, Yaniv Z, Mahajna J. Ethnobotanical survey in the Palestinian area: a classification of the healing potential of medicinal plants. J Ethnopharmacol. 2000;73(1):221-32

35. Benítez G, González-Tejero M, Molero-Mesa J. Pharmaceutical ethnobotany in the western part of Granada province (southern Spain): Ethnopharmacological synthesis. J Ethnopharmacol. 2010;129(1):87-105. 
36. Salama M. Diuretic plant ecology and medicine in the western Mediterranean coastal region of Egypt. Sciences. 2001;1(4):258-66.

37. Zohra M, Fawzia A. Hemolytic activity of different herbal extracts used in Algeria. Int J Pharm Sci Research. 2014;5:8495-4.

38. Bouanani S, Henchiri C, Migianu-Griffoni E, Aouf N, Lecouvey M. Pharmacological and toxicological effects of Paronychia Argentea in experimental calcium oxalate nephrolithiasis in rats. J Ethnopharmacol. 2010;129(1):38-45.

39. Zohra M, Fawzia A. Hemolytic activity of different herbal extracts used in Algeria. Int J Pharm Sci Res. 2014;5:8495-4.

40. Galisteo M, Sánchez M, Vera R, González M, Anguera A, Duarte J, Zarzuelo A. A diet supplemented with husks of Plantago Ovata reduces the development of endothelial dysfunction, hypertension, and obesity by affecting adiponectin and TNF-a in obese Zucker rats. J Nutr. 2005;135(10):2399-404.

41. Erum A, Bashir S, Saghir S, Tulain UR, Saleem U, Nasir M, Kanwal F. Hayat malik MN: acute toxicity studies of a novel excipient arabinoxylan isolated from Ispaghula (Plantago Ovata) husk. Drug Chem Toxicol. 2015;38(3):300-5.

42. Ballabh B, Chaurasia O, Ahmed Z, Singh SB. Traditional medicinal plants of cold desert Ladakh — used against kidney and urinary disorders. J Ethnopharmacol. 2008;118(2):331-9.

43. Zahid I, Bawazir A, Naser R. Plant based native therapy for the treatment of kidney stones in Aurangabad (MS). J Pharmacogn Phytochem. 2013;1(6):189-93.

44. Rani S, Rana J, Jeelani S, Gupta R, Kumari S. Ethnobotanical notes on 30 medicinal polypetalous plants of district Kangra of Himachal Pradesh. J Med Plants Res. 2013;7(20):1362-9.

45. Center DWs: Herbal and nutritional treatment of kidney stones. J Am Herb Guild 2012, 10(2):61-71.

46. Rathod N, Biswas D, Chitme H, Ratna S, Muchandi I, Chandra R. Antiurolithiatic effects of Punica Granatum in male rats. J Ethnopharmacol. 2012;140(2):234-8.

47. Tugcu V, Kemahli E, Ozbek E, Arinci YV, Uhri M, Erturkuner P, Metin G, Seckin I, Karaca C, Ipekoglu N. Protective effect of a potent antioxidant, pomegranate juice, in the kidney of rats with nephrolithiasis induced by ethylene glycol. J Endourol. 2008;22(12):2723-32.

48. Leporatti ML, Ivancheva S. Preliminary comparative analysis of medicinal plants used in the traditional medicine of Bulgaria and Italy. J Ethnopharmacol. 2003;87(2):123-42.

49. Gurukar A, Nandini CD, Mahadevamma S, Salimath P. Ocimum sanctum And Morus Alba leaves and Punica Granatum seeds in diet ameliorate diabetesinduced changes in kidney. J Pharm Res. 2012;5(9):4729-33.

50. Sandhu DS, Heinrich M. The use of health foods, spices and other botanicals in the Sikh community in London. Phytother Res. 2005;19(7):633-42.

51. Abu-Rabia A. Herbs as a food and medicine source in Palestine. Asian Pac J Cancer Prev. 2005:6(3):404

52. Maxia A, Lancioni MC, Balia AN, Alborghetti R, Pieroni A, Loi MC. Medical ethnobotany of the Tabarkins, a Northern Italian (Ligurian) minority in south-western Sardinia. Genet Resour Crop Evol. 2008;55(6):911-24.

53. Akbulut S, Bayramoglu MM. The trade and use of some medical and aromatic herbs in Turkey. Stud Ethno-Med. 2013;7(2):67-77.

54. Šarić-Kundalić B, Dobeš C, Klatte-Asselmeyer V, Saukel J. Ethnobotanical study on medicinal use of wild and cultivated plants in middle, south and west Bosnia and Herzegovina. J Ethnopharmacol. 2010;131(1):33-55.

55. Jarić S, Popović Z, Mačukanović-Jocić M, Djurdjević L, Mijatović M, Karadžić B, Mitrović M, Pavlović P: An ethnobotanical study on the usage of wild medicinal herbs from Kopaonik Mountain (Central Serbia). J Ethnopharmacol 2007, 111(1):160-175.

56. Faridi P, Roozbeh J, Mohagheghzadeh A. Ibn-Sina's life and contributions to medicinal therapies of kidney calculi. Iran J Kidney Dis. 2012;6(5):339.

57. Rahimmalek M, Maghsoudi H, Sabzalian M, Ghasemi Pirbalouti A. Variability of essential oil content and composition of different Iranian Fennel (Foeniculum Vulgare Mill.) accessions in relation to some morphological and climatic factors. J Agr Sci Tech. 2014;16(6):1365-3174.

58. Mahmood A, Mahmood A, Malik RN, Shinwari ZK. Indigenous knowledge of medicinal plants from Gujranwala district. Pakistan J Ethnopharmacol. 2013;148(2):714-23.

59. Kala CP, Farooquee NA, Majila B. Indigenous knowledge and medicinal plants used by Vaidyas in Uttaranchal. India Nat Prod Radiance. 2005;4(3):195-204
60. Macía MJ, Garcia E, Vidaurre PJ. An ethnobotanical survey of medicinal plants commercialized in the markets of La Paz and el alto. Bolivia J Ethnopharmacol. 2005;97(2):337-50.

61. Ibrahim FY, El-Khateeb A. Effect of herbal beverages of Foeniculum Vulgare and Cymbopogon Proximus on inhibition of calcium oxalate renal crystals formation in rats. Ann Agric Sci. 2013:58(2):221-9.

62. Shah A, Qureshi S, Ageel A. Toxicity studies in mice of ethanol extracts of Foeniculum Vulgare fruit and Ruta chalepensis aerial parts. J Ethnopharmacol. 1991;34(2-3):167-72.

63. Cakilcioglu U, Khatun S, Turkoglu I, Hayta S. Ethnopharmacological survey of medicinal plants in Maden (Elazig-Turkey). J Ethnopharmacol. 2011;137(1):469-86.

64. Kozuharova E, Lebanova H, Getov I, Benbassat N, Napier J. Descriptive study of contemporary status of the traditional knowledge on medicinal plants in Bulgaria. Afr J Pharm Pharmacol. 2013;7(5):185-98.

65. Mikawlrawng K, Kumar S. Current scenario of urolithiasis and the use of medicinal plants as antiurolithiatic agents in Manipur (north East India): a review. Int J Herb Med. 2014;2(1):1-12.

66. Egamberdieva D, Mamadalieva N, Khodjimatov O, Tiezzi A. Medicinal plants from Chatkal biosphere reserve used for folk medicine in Uzbekistan. Med Aromat Plant Sci Biotechnol. 2012;7(1):56-64.

67. Grosso C, Vinholes J, Silva LR. Pinho PGd, Gonçalves RF, Valentão P, Jäger AK, Andrade PB: chemical composition and biological screening of Capsella Bursa-Pastoris. Rev Bras Farmacogn. 2011;21(4):635-43.

68. Choi WJ, Kim SK, Park HK, Sohn UD, Kim W. Anti-inflammatory and antisuperbacterial properties of sulforaphane from Shepherd's purse. Korean $J$ Physiol Pharmacol. 2014;18(1):33-9.

69. Al-Snafi AE. The chemical constituents and pharmacological effects of Capsella Bursa-Pastoris-a review. Int J Pharm Sci Res Tox. 2015;5(2):76-81.

70. Zennie TM, Ogzewalla D. Ascorbic acid and vitamin a content of edible wild plants of Ohio and Kentucky. Econ Bot. 1977;31(1):76-9.

71. Kweon M-H, Kwak J-H, Ra K-S, Sung H-C, Yang H-C. Structural characterization of a flavonoid compound scavenging superoxide anion radical isolated from Capsella Bursa-Pastoris. BMB Rep. 1996;29(5):423-8.

72. Leporatti ML, Ghedira K. Comparative analysis of medicinal plants used in traditional medicine in Italy and Tunisia. J Ethnobiol Ethnomed. 2009:5(1):1.

73. El-Mokasabi F. The state of the art of traditional herbal medicine in the eastern mediterranean coastal region of Libya. Middle East J Sci Res. 2014;21(4):575-82

74. Khalid H, Abdalla WE, Abdelgadir H, Opatz T, Efferth T. Gems from traditional north-African medicine: medicinal and aromatic plants from Sudan. Nat prod bioprospect. 2012;2(3):92-103.

75. El-Seedi HR, Burman R, Mansour A, Turki Z, Boulos L, Gullbo J, Göransson U. The traditional medical uses and cytotoxic activities of sixty-one Egyptian plants: discovery of an active cardiac glycoside from Urginea maritima. J Ethnopharmacol. 2013;145(3):746-57.

76. Jan S, Khan K, Hameed I, Ahmad N. Ethnobotanical studies of the medicinal plants of Malakand agency, Khyber Pakhtunkhwa. Pakistan s. 2012;18(1):1-7.

77. Bussmann RW, Ashley G, Sharon D, Chait G, Diaz D, Pourmand K, Jonat B, Somogy S, Guardado G, Aguirre C. Proving that traditional knowledge works: the antibacterial activity of Northern Peruvian medicinal plants. Ethnob Res Appl. 2011;9:067-96.

78. Hudson J, Towers GN. Phytomedicines as antivirals. Drugs Future. 1999;24(3): 295-301.

79. Hashim S, Jan A, Marwat KB, Khan MA. Phytochemistry and medicinal properties of Ammi Visnaga (Apiacae). Pak J Bot. 2014;46(3):861-7.

80. Leporatti ML, Guarrera PM. Ethnobotanical remarks in Capitanata and Salento areas (Puglia, southern Italy). Etnobiología. 2015;5(1):51-64.

81. Lev $E$, Amar Z. Ethnopharmacological survey of traditional drugs sold in the Kingdom of Jordan. J Ethnopharmacol. 2002;82(2):131-45.

82. Rhattas M, Douira A, Zidane L. Ethnobotanical study of medicinal plants in the Talassemtane Nationall Park (western Rif of Morocco). J Appl Biosci. 2016:97:9187-211.

83. Al Akeel R, Al-Sheikh Y, Mateen A, Syed R, Janardhan K, Gupta V. Evaluation of antibacterial activity of crude protein extracts from seeds of six different medical plants against standard bacterial strains. Saudi J Biol Sci. 2014:21(2):147-51

84. Egyed M, Malkinson M, Shlosberg A. Observations on the experimental poisoning of young geese with Ammi Majus. Avian Pathol. 1974;3(2):79-87.

85. Khare C. Indian medicinal plants. 1st ed. Berlin/Heidlburg: Springer; 2007. 
86. Sharma H, Kumar RA. Health security in ethnic communities through nutraceutical leafy vegetables. J Environ Res Develop. 2013;7(4):1423-31.

87. Sultana A, Rahman K: Portulaca oleracea Linn. A global panacea with ethnomedicinal and pharmacological potential. Int J Pharm Pharm Sci 2013, 5:33-39.

88. Chan K, Islam M, Kamil M, Radhakrishnan R, Zakaria M, Habibullah M, Attas A. The analgesic and anti-inflammatory effects of Portulaca Oleracea $L$. subsp. sativa (haw.) Celak. J Ethnopharmacol. 2000;73(3):445-51.

89. Lee AS, Lee YJ, Lee SM, Yoon JJ, Kim JS, Kang DG, Lee HS. An aqueous extract of Portulaca Oleracea ameliorates diabetic nephropathy through suppression of renal fibrosis and inflammation in diabetic $\mathrm{db} / \mathrm{db}$ mice. Am J Chin Med. 2012:40(03):495-510.

90. Karimi G, Khoei A, Omidi A, Kalantari M, Babaei J, Taghiabadi E, Razavi BM. Protective effect of aqueous and ethanolic extracts of Portulaca Oleracea against cisplatin induced nephrotoxicity. Iranian J Basic Med Sci. 2010;13(2):31-5.

91. Guil J, Rodríguez-Garcí I, Torija E. Nutritional and toxic factors in selected wild edible plants. Plant Foods Hum Nutr. 1997;51(2):99-107.

92. Fontana E, Hoeberechts J, Nicola S, Cros V, Battista Palmegiano G, Giorgio Peiretti P. Nitrogen concentration and nitrate/ammonium ratio affect yield and change the oxalic acid concentration and fatty acid profile of purslane (Portulaca Oleracea L.) grown in a soilless culture system. J Sci Food Agr. 2006:86(14):2417-24

93. Bahmani M, Rafieian M, Baradaran A, Rafieian S, Rafieian-kopaei M. Nephrotoxicity and hepatotoxicity evaluation of Crocus Sativus stigmas in neonates of nursing mice. J Nephropathol. 2014;3(2):81-91.

94. HosseinZadeh H, Sadeghi Shakib S, Khadem Sameni A, Taghiabadi E. Acute and subacute toxicity of safranal, a constituent of saffron, in mice and rats. Iranian J Pharm Res. 2013;12(1):93-9.

95. Ramadan A, Soliman G, Mahmoud SS, Nofal SM, Abdel-Rahman RF. Evaluation of the safety and antioxidant activities of Crocus Sativus and Propolis ethanolic extracts. J Saudi Chem Soc. 2012;16(1):13-21.

96. Saad B, Azaizeh H, Said O. Botanical Medicine in Clinical Practice. UK: CABI; 2008.

97. Paulsen MT, Ljungman M. The natural toxin juglone causes degradation of p53 and induces rapid H2AX phosphorylation and cell death in human fibroblasts. Toxicol Appl Pharmacol. 2005;209(1):1-9.

98. Shoskes D. Use of the bioflavonoid quercetin in patients with longstanding chronic prostatitis. J Am Neutraceutical Assoc. 1999;2:18-25.

99. Iminjan $\mathrm{M}, \mathrm{Amat} \mathrm{N}$, Li X-H, Upur $\mathrm{H}$, Ahmat D, He B. Investigation into the toxicity of traditional Uyghur medicine Quercus Infectoria galls water extract. PLoS One. 2014;9(3):e90756.

100. Genç GE, Özhatay N: An ethnobotanical study in Catalca (European part of Istanbul) Turkish J PharmSci 2006, 3(2):73-89.

101. Redzic S. Wild medicinal plants and their usage in traditional human therapy (southern Bosnia and Herzegovina, W. Balkan). J Medl Plants Res. 2010;4(11):1003-27.

102. Ebrahimzadeh MA, Mahmoudi M, Karami M, Saeedi S, Ahmadi AH, Salimi E. Separation of active and toxic portions in Sambucus Ebulus. Pak J Biol Sci. 2007;10(22):4171-3.

103. Sekkoum K, Cheriti A, Taleb S, Bourmita Y, Belboukhari N. Traditional phytotherapy for urinary diseases in Bechar district (south west of Algeria). Electron J Environ Agric Food Chem. 2011;10(8):2616-22.

104. Cáceres A, Girón LM, Martínez AM. Diuretic activity of plants used for the treatment of urinary ailments in Guatemala. J Ethnopharmacol. 1987;19(3):233-45.

105. Maksimović Z, Malenčić $Đ$, Kovačević N. Polyphenol contents and antioxidant activity of Maydis stigma extracts. Bioresour Technol. 2005;96(8):873-7.

106. Noumi E, Bouopda N. A review of prostate diseases at yaounde: epidemiology, prophylaxy and phytotherapy. Indian J Tradit Knowl. 2014;13(1):36-46

107. Monigatti M, Bussmann RW, Weckerle CS. Medicinal plant use in two Andean communities located at different altitudes in the Bolívar Province. Peru J Ethnopharmacol. 2013;145(2):450-64

108. Wojcikowski K, Wohlmuth H, Johnson DW, Rolfe M, Gobe G. An in vitro investigation of herbs traditionally used for kidney and urinary system disorders: potential therapeutic and toxic effects. Nephrology. 2009;14(1):70-9.

109. Kuhnen S, Bernardi Ogliari J, Dias PF, da Silva SM, Ferreira AG, Bonham CC, Wood KV, Maraschin M. Metabolic fingerprint of Brazilian maize landraces silk (stigma/styles) using NMR spectroscopy and chemometric methods. J Agric Food Chem. 2010;58(4):2194-200.
110. Sağıroğlu M, Dalgıç S, Toksoy S. Medicinal plants used in Dalaman (Muğla) Turkey J Med Plant Res. 2013;7(28):2053-66.

111. Habtemariam S. Extract of corn silk (stigma of Zea Mays) inhibits the tumour necrosis factor-alpha-and bacterial lipopolysaccharide-induced cell adhesion and ICAM-1 expression. Planta Med. 1998;64(4):314-8.

112. Wang C, Zhang T, Liu J, Lu S, Zhang C, Wang E, Wang Z, Zhang Y, Liu J. Subchronic toxicity study of corn silk with rats. J Ethnopharmacol. 2011;137(1):36-43.

\section{Submit your next manuscript to BioMed Central and we will help you at every step:}

- We accept pre-submission inquiries

- Our selector tool helps you to find the most relevant journal

- We provide round the clock customer support

- Convenient online submission

- Thorough peer review

- Inclusion in PubMed and all major indexing services

- Maximum visibility for your research

Submit your manuscript at www.biomedcentral.com/submit
C) Biomed Central 